\title{
UNIAXIAL COMPRESSIVE STRENGTH, DRY UNIT WEIGHT AND FRACTURE PATTERNS OF ULTRABASIC ROCKS IN OTHRYS MOUNTAIN (CENTRAL GREECE): CORRELATIONS AND EVALUATION.
}

\author{
Diamantis K. ${ }^{1}$, Karamousalis Th. ${ }^{1}$, Antoniou Vas. ${ }^{1}$, and Migiros G. ${ }^{1}$ \\ ${ }^{1}$ Agricultural University of Athens, Department of Sciences, Division of Geological Science and \\ Atmospheric Environment, Laboratory of Mineralogy-Geology, kostasdiam@aua.gr, \\ karamousalis@aua.gr,vantoniou@aua.gr,bagm@aua.gr
}

\begin{abstract}
Ultrabasic rocks, taken from the Othrys mt. (Central Greece), are studied in this paper. The structural geology and tectonics of the study area are described. Uniaxial Compressive Strength (UCS) and dry unit weight $(\gamma)$ values are calculated and fracture angles are measured. The results are statistically assessed and empirical relationships (exponential equations) between UCS and $\gamma$ are presented for the ultrabasic rocks, divided in Peridotites, Serpentinised Peridotites and Serpentinites. Due to the low correlation coefficient of the Serpentinised Peridotites, it was decided that the Serpentinised Peridotites and Serpentinites should be examined together. The correlation coefficient of the combined category is much better than the separate ones.

Furthermore, this paper demonstrates that the majority of the ultrabasic rocks tested were breaking at one angle $\left(\varphi^{\circ}\right)$, which mainly fluctuated between $75^{\circ}$ and $90^{\circ}$. The fracture angles correlate with previously recognised geological (mainly tectonic) structures.

The observed deviations are due to petrographic variety, structural complexity, preferred orientation of olivine and orthopyroxene and internal imprinted tectonic deformation.
\end{abstract}

Key words: Rock mechanics, ophiolites, laboratory tests.

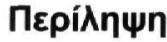

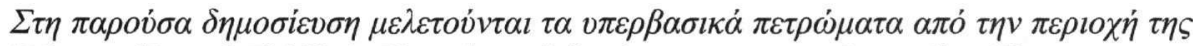

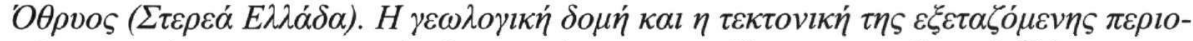

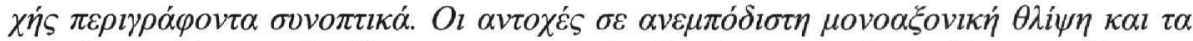

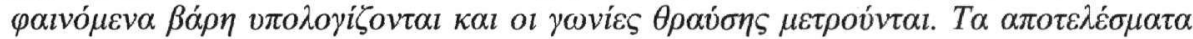

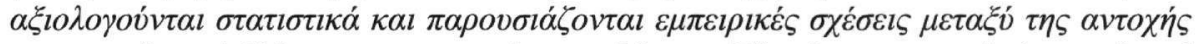

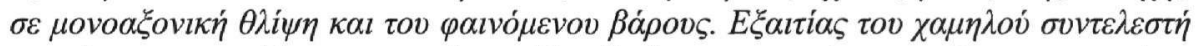

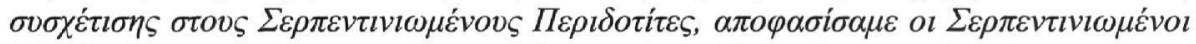

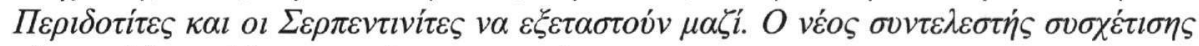

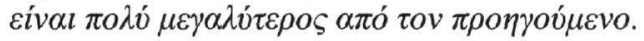




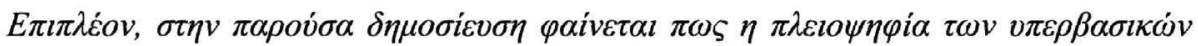

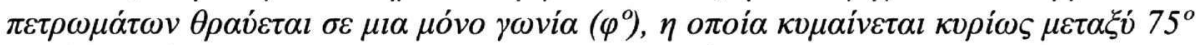

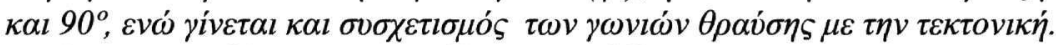

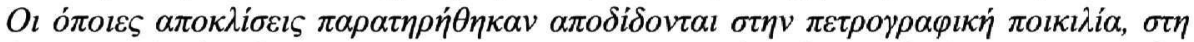

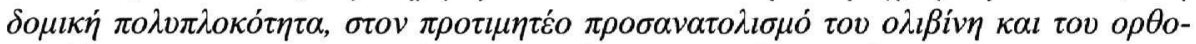

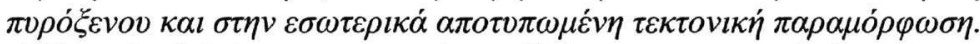

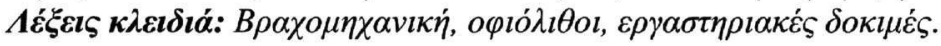

\section{Introduction}

Many attempts have been to correlate the Uniaxial Compressive Strength (UCS), which is undoubtedly the geotechnical property of rocks which is most often quoted, with certain mechanical and physical characteristics. Nevertheless, only few studies have been concentrated on ultrabasic rocks (Koumantakis 1982, Paventi et al. 1996, Marinos et al. 2006). An opportunity to conduct such investigation came up when the Laboratory of Mineralogy-Geology of the Agricultural University of Athens undertook the geomechanical tests from ERGOSE S.A. for the construction of railway tunnels in Othrys $\mathrm{mt}$.

The study area is located in Othrys (Central Greece) and specifically between the villages of Lianokladi and Domokos (Fig. 1). It belongs to the Sub-Pelagonian geotectonical unit and it is mainly comprised of ultrabasic rock masses (Marinos 1974, Migiros 1990).

A number of boreholes were drilled along a narrow N-S zone, from which 138 representative samples were chosen to be examined.

Uniaxial Compressive Strength and dry unit weight $(\gamma)$ values were calculated following the international standards. Photographs were taken before and after each test, fracture patterns were drawn, the angles were measured and statistically classified.

Within the framework of the present study, the fluctuations of UCS and $\gamma$ values and the statistical analysis of the fracture angles are presented. This paper attempts to derive reliable empirical equations between UCS and $\gamma$, to correlate them with both fracture angles and depth and to outline the influence of the geological structure.

\section{Materials and methods}

Drill core samples from the Othrys mt. were investigated for geotechnical purposes (construction of railway tunnels by ERGOSE S.A.) in the Laboratory of Mineralogy-Geology of the Agricultural University of Athens. The boreholes were carried out in a $25 \mathrm{~km}$ long N-S direction, from Lianokladi to Domokos villages, perpendicular to the geological and tectonic structures of the area and they were drilled at depths up to $300 \mathrm{~m}$ from the surface. The wide range of sample depth along with the quite large numbers of samples, render our results representative for the Othrys ultrabasic rock masses.

The initial choice of the samples and the sequence of tests were decided by the supervising rock mechanics engineer and geologists. At our laboratory a second check was done by taking into account the isotropy and homogeneity of the samples and some were disqualified as inappropriate (about $33 \%$ ), mainly due to visible discontinuities, i.e. fractures, reducing the number of samples to 138 .

Due to the variable grade of serpentinisation of the peridotite samples, many thin sections were cut and examined under a polarising microscope and some samples were further analysed by the XRD method. Three petrologic types of peridotites were distinguished based on their different physical and mechanical properties. 
The Uniaxial Compressive Strength (UCS) tests were carried out in accordance with the ISRM (1981) standard. The core samples, whose diameters were 61,71 and $83 \mathrm{~mm}$, were carefully prepared keeping an L/D ratio between 2,5 and 3,0. The edges of the samples were cut parallel and smooth. The samples were then oven dried and before every test the samples were weighted with accuracy in order to calculate the dry unit weight. After each test, the pattern of the fractures was drawn and the angles of the fractures were measured.

The data was analysed with the Analysis Tool Pack of Microsoft Excel 2003 and the results were evaluated and then correlated with the geological structures of the area.

\section{Geology}

The area between the Lianokladi and Domokos villages (Othrys mt.) consists mainly of Alpine formations (Fig. 1) that belong to the Sub-Pelagonian geotectonic unit (Mountrakis et al. 1983, Katsikatsos et al. 1986). We can distinguish them, from bottom to top, in the following formations (Marinos 1974, Ferriere 1982, Migiros 1990):

(a) A carbonate sequence of Triassic-Jurassic age which constitutes the basement of the area.

(b) A tectonic nappe, mainly ophiolitic (Katsikatsos et al. 1986).

(c) An unconformable sequence of Cretaceous limestones which passes upward to flysch.

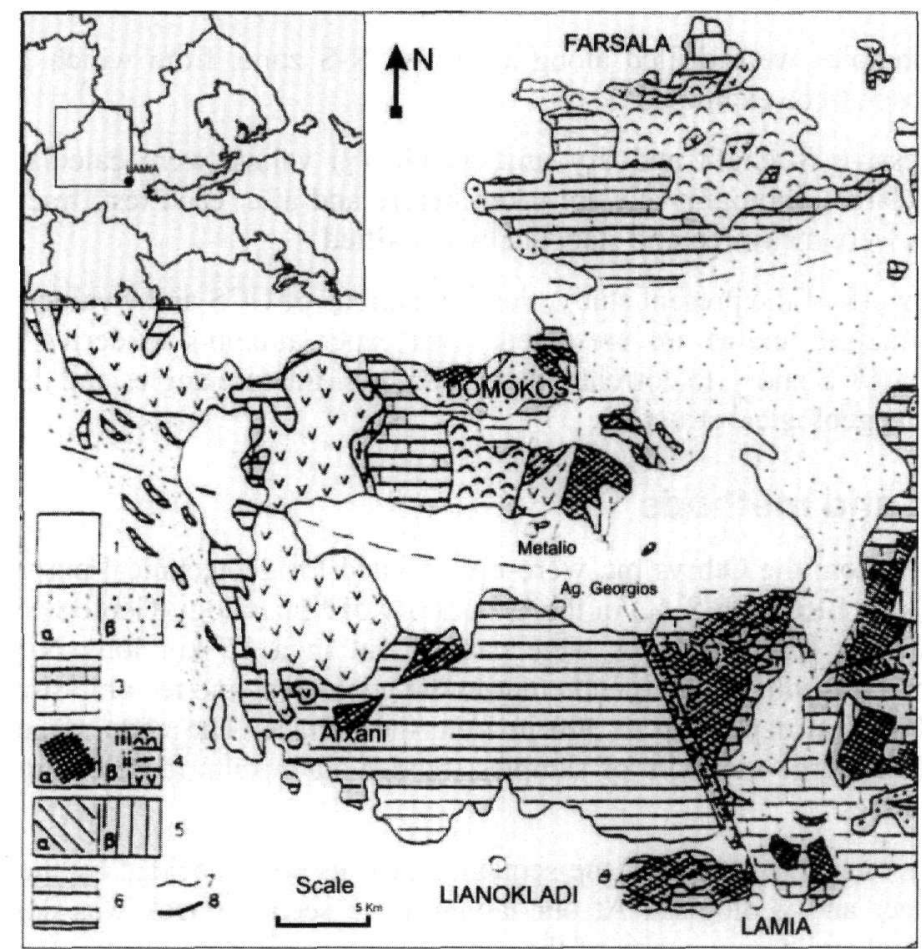

Figure 1 - Geological map of Othrys area (Migiros 1990): 1. Postalpine formations 2. Flysch

$(\alpha)$ Paleocene - Eocene ( $\beta$ ) Upper Cretaceous 3. Cretaceous formations of eastern and central Othrys 4. Pre-Upper Cretaceous tectonic nappe ( $\alpha$ ) Undivided ( $\beta$ ) Ophiolitic formations (i) tectonites (ii) cumulates (iii) non-cumulites and volcanic sequence 5 . PreCretaceous formations $(\alpha)$ eastern $(\beta)$ central Othrys 6. Western Othrys formations (undivided) 7. Geological boundary 8 . Tectonic contact

The ophiolitic formations have thrusted the Triassic-Jurassic carbonate sequence and are consisted of volcano-sedimentary formations, basaltic lavas, basic rocks and ultrabasic masses. The 
ultrabasic rock masses are mainly represented by the peridotites whose grade of serpentinisation varies.

In our study we classified the peridotite samples into the following three rock groups taking into account petrological and mineralogical studies:

(a) Peridotites: We refer mainly to lerzoliths, hartzbourgites and plagioclastic peridotites with a grade of serpentinisation less than $30 \%$.

(b) Serpentised Peridotites: The same rock type but its grade of serpentinisation lies between $30 \%$ and $70 \%$.

(c) Serpentinites: Ultrabasic rock types, mainly hartzbourgites, whose grade of serpentinisation is more than $70 \%$.

According to Migiros 1990, the tectonic analysis of the geological formations exhibits the following prominent tectonic features in the ultrabasic rock masses:

(a) Schistosity: NW-SE direction and NE dip less than $30^{\circ}$.

(b) Low thrusts: E-W direction and $\mathrm{N}$ dip between $30^{\circ}-45^{\circ}$.

(c) Thrusts: NW-SE direction and NE dip between $45^{\circ}-60^{\circ}$.

(d) Faults: E-W, NW-SE, NE-SW directions and dips more than $60^{\circ}$.

\section{Laboratory test results}

\subsection{Dry unit weight $(y)$}

The dry unit weight was calculated for the total number of 138 ultrabasic samples and their values are illustrated in Figure 2. As seen in Table 1 (statistical analysis), the dry unit weight fluctuates between 22.99 and $33.77 \mathrm{kN} / \mathrm{m}^{3}$ and the average value is $27.64 \mathrm{kN} / \mathrm{m}^{3}$.

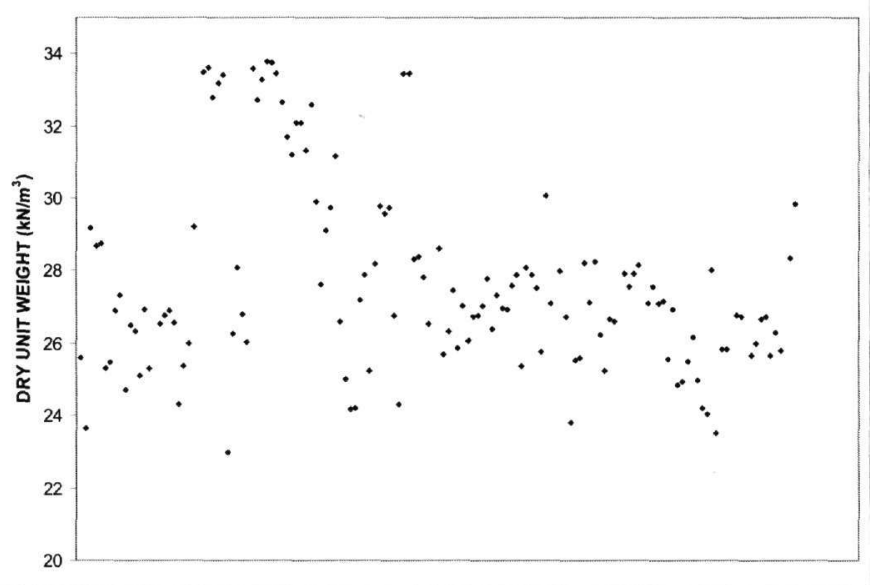

Figure 2 - Dry Unit weight values of the investigated ultrabasic samples

The ultrabasic rocks, based on their dry unit weight and taking into account their petrological studies are divided in Peridotites, Serpentinised Peridotites and Serpentinites.

The dry unit weights of Peridotites range from $29.56 \mathrm{kN} / \mathrm{m}^{3}$ to $33.77 \mathrm{kN} / \mathrm{m}^{3}$, those of Serpentinites from $22.99 \mathrm{kN} / \mathrm{m}^{3}$ to $25.98 \mathrm{kN} / \mathrm{m}^{3}$ and the values of Serpentinised Peridotites vary from 26.00 $\mathrm{kN} / \mathrm{m}^{3}$ to $29.19 \mathrm{kN} / \mathrm{m}^{3}$ (Table 2 ). 
From the above mentioned and taking into account the low standard deviations of the groups that were formed petrologically, we conclude that there is also a clear differentiation to the dry unit weight values, as it was expected, which is due to the grade of serpentisation.

Table 1 - Statistical analysis results of the investigated ultrabasic samples

\begin{tabular}{|c|c|}
\hline \multicolumn{2}{|c|}{ ULTRABASIC ROCKS } \\
\hline & DRY UNIT WEIGHT $\left(\mathrm{KN} / \mathrm{m}^{3}\right)$ \\
\hline MAX & 33,77 \\
\hline MIN & 22.99 \\
\hline MEAN & 27.64 \\
\hline STDEV & 2.62 \\
\hline
\end{tabular}

Table 2 - Statistical analysis results of the investigated ultrabasic samples.

\begin{tabular}{|c|c|c|}
\hline & & DRY UNIT WEIGHT $\left(\mathrm{KN} / \mathrm{m}^{3}\right)$ \\
\hline \multirow{4}{*}{ PERIDOTITES } & MAX & 33.77 \\
\cline { 2 - 3 } & MIN & 29.56 \\
\cline { 2 - 3 } & MEAN & 32.04 \\
\cline { 2 - 3 } SERPENTINISED & STDEV & 1.52 \\
\hline \multirow{4}{*}{ PERIDOTITES } & MAX & 29.19 \\
\cline { 2 - 3 } & MIN & 26.00 \\
\cline { 2 - 3 } & MEAN & 27.29 \\
\cline { 2 - 3 } & STDEV & 0.81 \\
\hline \multirow{5}{*}{ SERPENTINITES } & MAX & 25.98 \\
\cline { 2 - 3 } & MIN & 22.99 \\
\cline { 2 - 3 } & MEAN & 25.02 \\
\cline { 2 - 3 } & STDEV & 0.77 \\
\hline
\end{tabular}

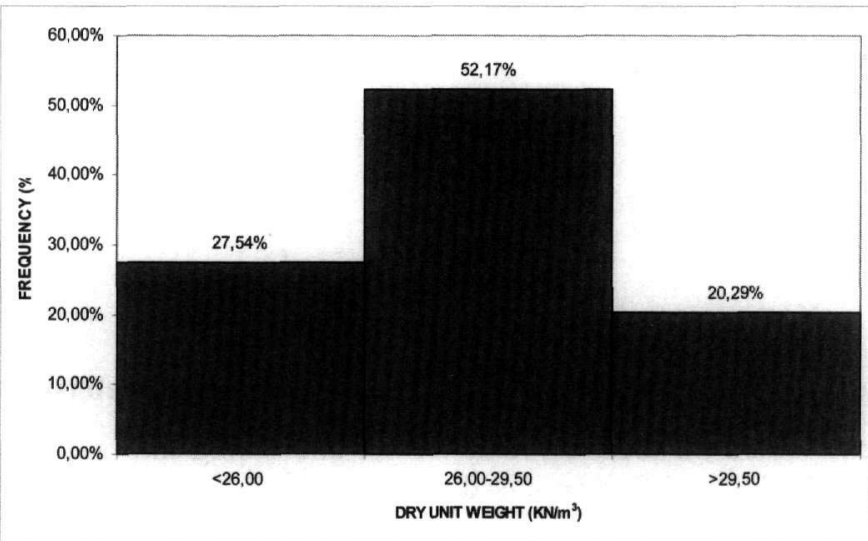

Figure 3 - Dry unit weight histogram

Finally based on the results of the dry unit weight statistical analysis for each petrological group and regarding $29.50 \mathrm{kN} / \mathrm{m}^{3}$ as the minimum value for Peridotites and $26.00 \mathrm{kN} / \mathrm{m}^{3}$ as the 
maximum value for Serpentinites, a histogram was created (Fig. 3). As can be seen the largest number of samples belong to Serpentinised Peridotites $(52.17 \%)$.

\subsection{Uniaxial Compressive Strength (UCS)}

A scatter diagram of all UCS values is illustrated in Figure 4. The UCS values range from 169.63 to $0.40 \mathrm{MPa}$ exhibiting a great fluctuation. Some very uncommon low values of UCS are due to internal discontinuities, macroscopically undetected. The mean value is $53.62 \mathrm{MPa}$ and the standard deviation is $35.34 \mathrm{MPa}$ (Table 3). The high value of the standard deviation can be attributed to the fact that the majority of the samples belong to the Serpentinised Peridotites group $(52.17 \%)$, which exhibit great anisotropy.

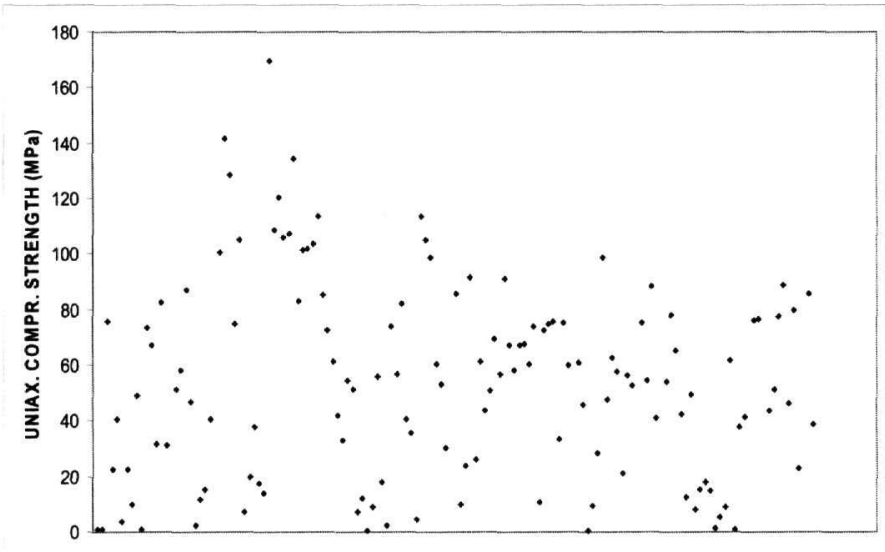

Figure 4 - Uniaxial Compressive Strength values of the investigated samples

Table 3 - Statistical analysis results of the investigated ultrabasic samples

\begin{tabular}{|c|c|}
\hline \multicolumn{2}{|c|}{ ULTRABASIC ROCKS } \\
\hline & $\begin{array}{c}\text { UNIAXIAL COMPRESSIVE } \\
\text { STRENGTH } \\
(\mathrm{MPa})\end{array}$ \\
\hline MAX & 169.63 \\
\hline MIN & 0.40 \\
\hline MEAN & 53.62 \\
\hline STDEV & 35.34 \\
\hline
\end{tabular}

\subsection{Fracture Angles $\left(\varphi^{\circ}\right)$}

Following the UCS tests, photographs of the samples were taken and fracture patterns were drawn. Of the 138 samples, $86.96 \%$ had single dipping fractures, while the $13.04 \%$ was broken in two angles (Fig. 5). These two groups of samples were statistically analyzed separately. After distinguishing four bins $\left(30^{\circ} \leq \varphi^{\circ}<45^{\circ}, 45^{\circ} \leq \varphi^{\circ}<60^{\circ}, 60^{\circ} \leq \varphi^{\circ}<75^{\circ}, 75^{\circ} \leq \varphi^{\circ} \leq 90^{\circ}\right)$, it is shown that both groups were mainly broken in angles between $75^{\circ}$ and $90^{\circ}$ (Figs 6,7 ). In addition, no fracture angle values less than $30^{\circ}$ were observed. Detailed statistical analysis is shown in Table 4.

Finally, for each sample the dominant angle was identified. A histogram of the prevalent fracture angles is shown in Figure 8. It is evident that the majority of the samples $(60.14 \%)$ had a prevalent fracture angle between $75^{\circ}$ and $90^{\circ}$, while only the $2.17 \%$ broke between $30^{\circ}$ and $44^{\circ}$. 


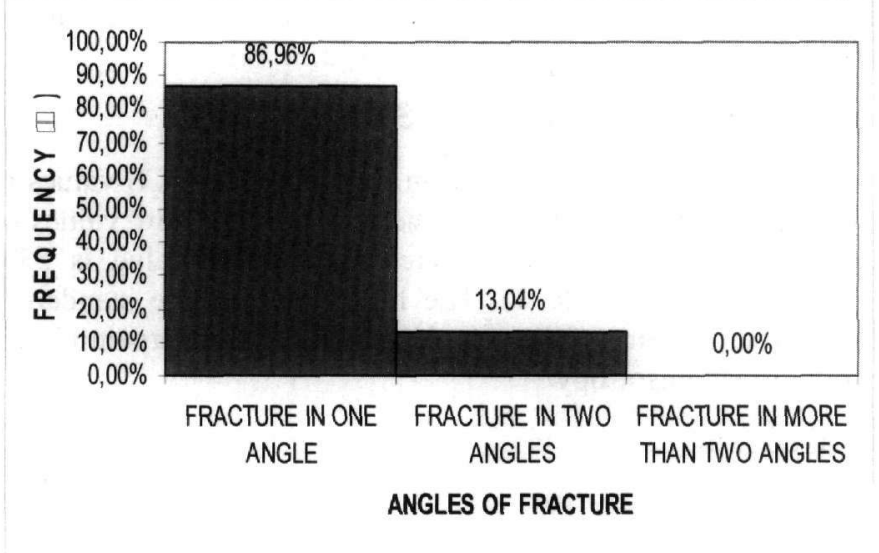

Figure 5 - Frequency of the fracture angles

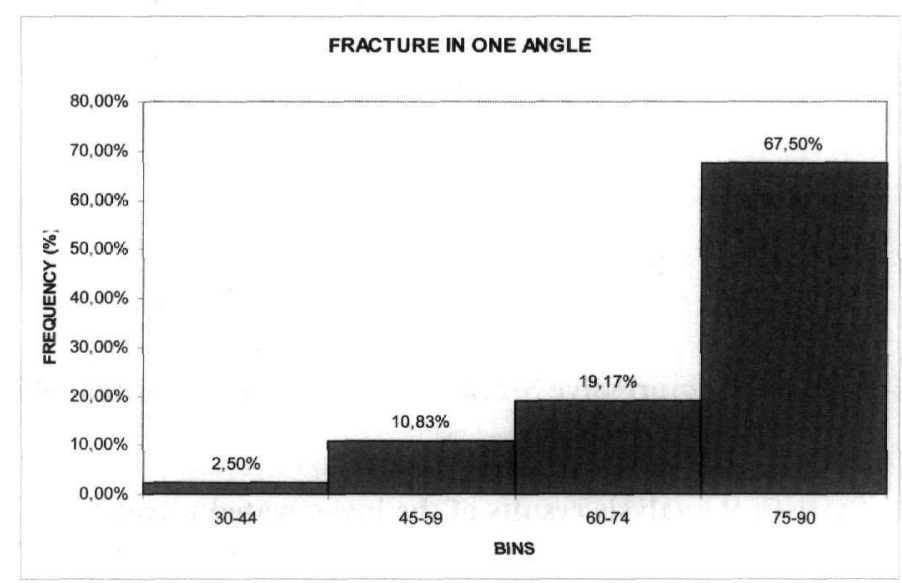

Figure 6 - Frequency of one fracture angle

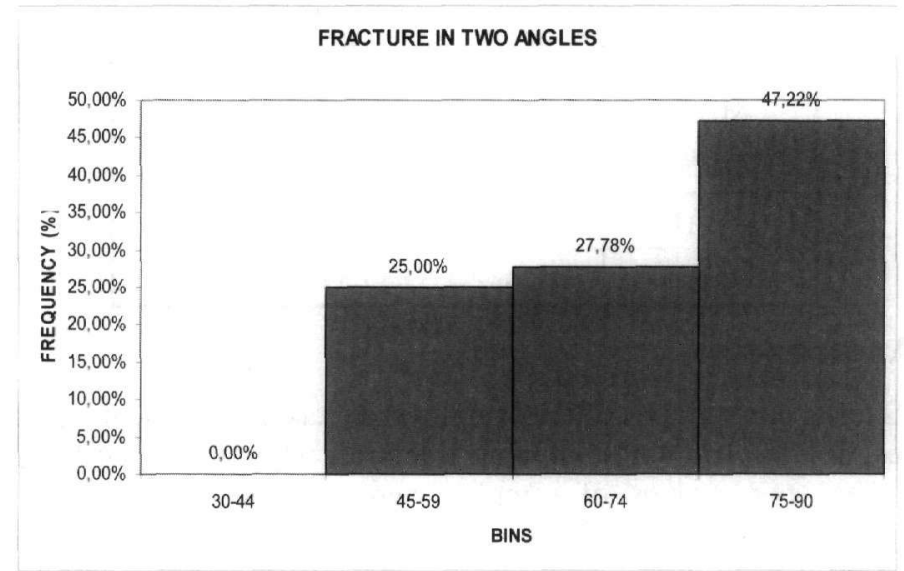

Figure 7 - Frequency of two fracture angles 
Table 4 - Statistical analysis results of fracture angles

\begin{tabular}{|c|c|c|c|c|c|c|c|c|}
\hline & \multicolumn{4}{|c|}{ FRACTURE IN ONE ANGLE } & \multicolumn{4}{c|}{ FRACTURE IN TWO ANGLES } \\
\hline BINS & $30-44$ & $45-59$ & $60-74$ & $75-90$ & $30-44$ & $45-59$ & $60-74$ & $75-90$ \\
\hline FREQUENCY & 3 & 13 & 23 & 81 & 0 & 9 & 10 & 17 \\
\hline $\begin{array}{c}\text { FREQUENCY } \\
(\%)\end{array}$ & $2,50 \%$ & $10,83 \%$ & $19,17 \%$ & $67,50 \%$ & $0,00 \%$ & $25,00 \%$ & $27,78 \%$ & $47,22 \%$ \\
\hline MEAN & 37,33 & 55,69 & 67,48 & 84,15 & 0 & 52,00 & 67,10 & 82,41 \\
\hline MODE & 42 & 54 & 70 & 85 & 0 & 50 & 64 & 85 \\
\hline
\end{tabular}

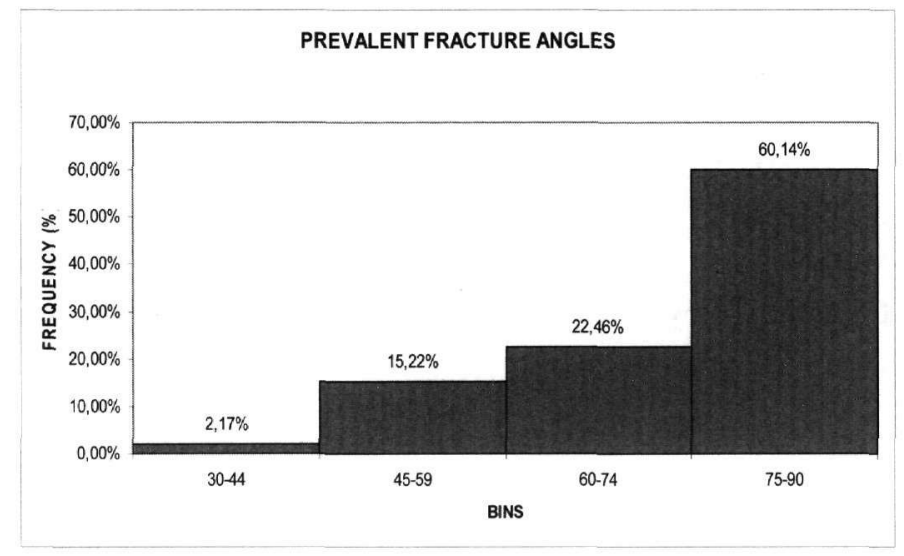

Figure 8 - Histogram of the prevalent fracture angles

\section{Results \& Discussion}

The statistical analysis software used to correlate UCS and dry unit weight was the Analysis Tool Pack of the Microsoft Excel 2003. Figure 9 is a plot diagram of UCS against $\gamma$ for the total number of the samples. The relationship gives a good correlation coefficient $(\mathrm{R}=0.66)$ and is defined by the equation $\mathrm{UCS}=0.0063 \mathrm{e}^{0.3117 \gamma}$. A closer examination of Figure 9 reveals a discrepancy of the normally exponential relationship between dry unit weight and UCS. This is attributed to the anisotropic single-crystal elastic properties and the lattice preferred orientation of olivine and orthopyroxene. Specifically for the Peridotites, the relationship between UCS and $\gamma$ gives a high correlation coefficient $(\mathrm{R}=0.78)$ and is represented by $\mathrm{UCS}=0.2067 \mathrm{e}^{0.1892 \cdot \gamma}$ (Fig. 10). The same relationship gives a low correlation coefficient $(\mathrm{R}=0.26)$ for Serpentinised Peridotites (Fig. 11) and a good one ( $\mathrm{R}=0.66)$ for Serpentinites (Fig. 12). Thus it is suggested that Serpentinised Peridotites and Serpentinites should be examined together. The new correlation coefficient is 0.74 and the equation is defined by the UCS $=3 \cdot 10^{-7} \mathrm{e}^{0.6962 \cdot \gamma}$ (Fig. 13). Moreover, the deviations are due to the varied grade of serpentinisation, the petrographic variety (hartzburgites, lerzolites, plagioclastic peridotites) and the internal structural complexity due to the tectonic deformation and alteration.

It can be seen from Figures 5-6, that the majority of the ultrabasic samples broke in one angle, which predominately fluctuated between $75^{\circ}$ and $90^{\circ}$. When samples fractured in two angles, the percentage of the bins $45^{\circ}-59^{\circ}$ and $60^{\circ}-74^{\circ}$ increased while the percentage of the bin $75^{\circ}-90^{\circ}$ decreased (Fig. 7), which is quite reasonable.

From the aforementioned, it is obvious that the fracture angles of the samples deviate from the expected value of $45^{\circ}$. This is mainly attributed to the internal imprint of tectonic structures; specifically, angles lower than $45^{\circ}$ are related to low thrusts, between $45^{\circ}$ and $60^{\circ}$ to the thrusts and those with angles greater than $60^{\circ}$ are correlated to the faults and/or collapse effect. 
Finally, there is no obvious relationship between the UCS and the fracture angle as in between the fracture angle and the depth from which the samples were taken. As it is aforementioned, this is attributed to the petrographic variety and/or to the preferred orientation and the internally imprinted tectonic structures.

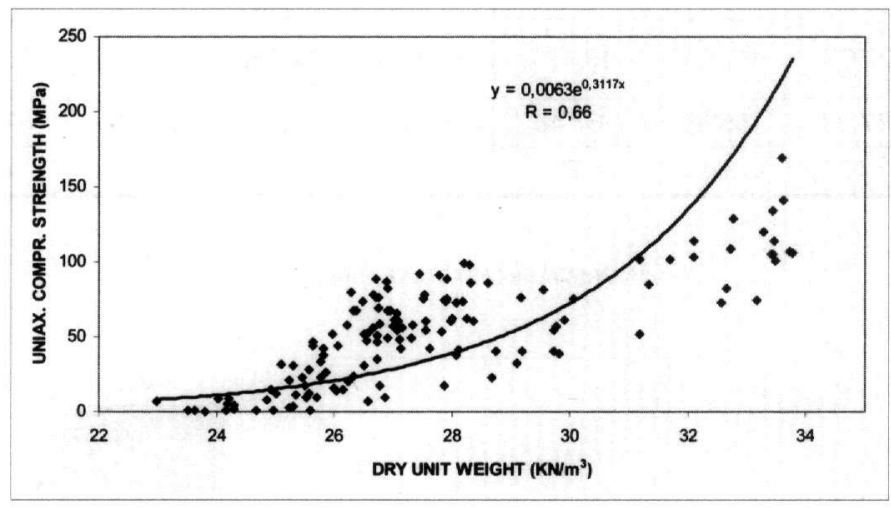

Figure 9 - UCS against Dry unit weight for the total number of ultrabasic samples

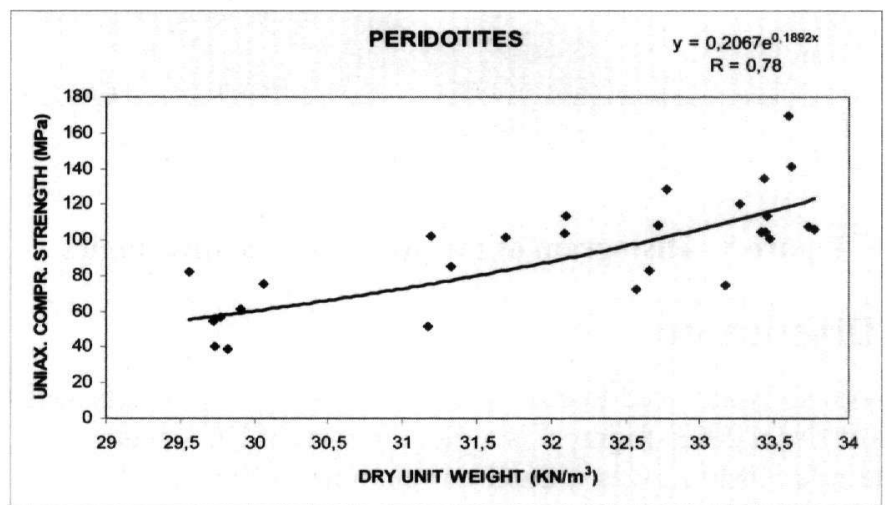

Figure 10 - UCS against Dry unit weight only for the Peridotites

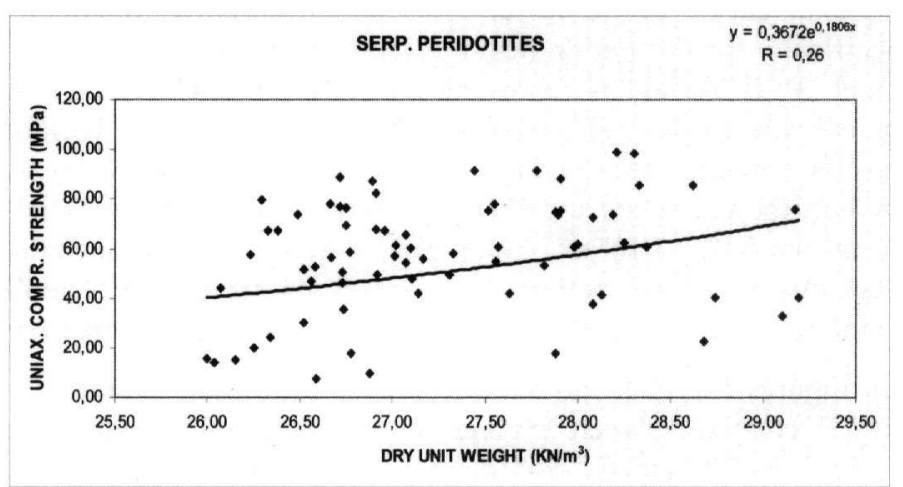

Figure 11 - UCS against Dry unit weight only for the Serpentinised Peridotites 


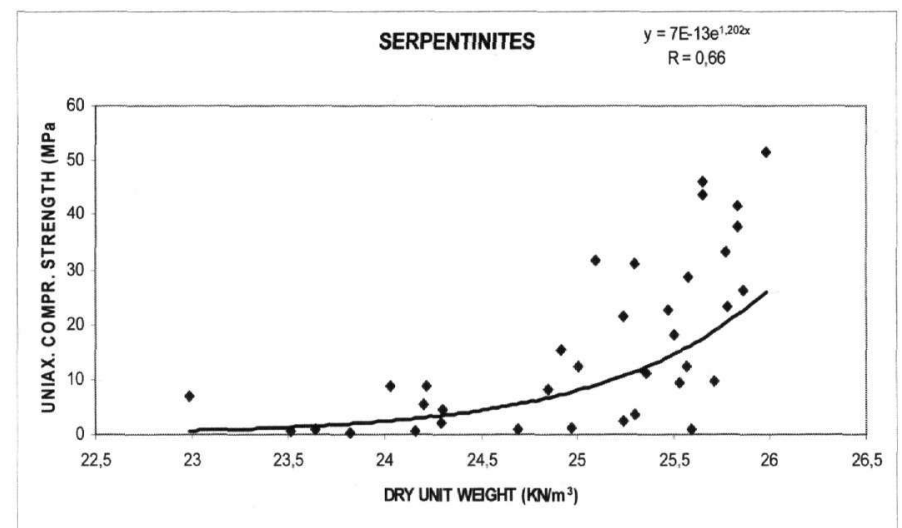

Figure 12 - UCS against Dry unit weight only for the Serpentinites

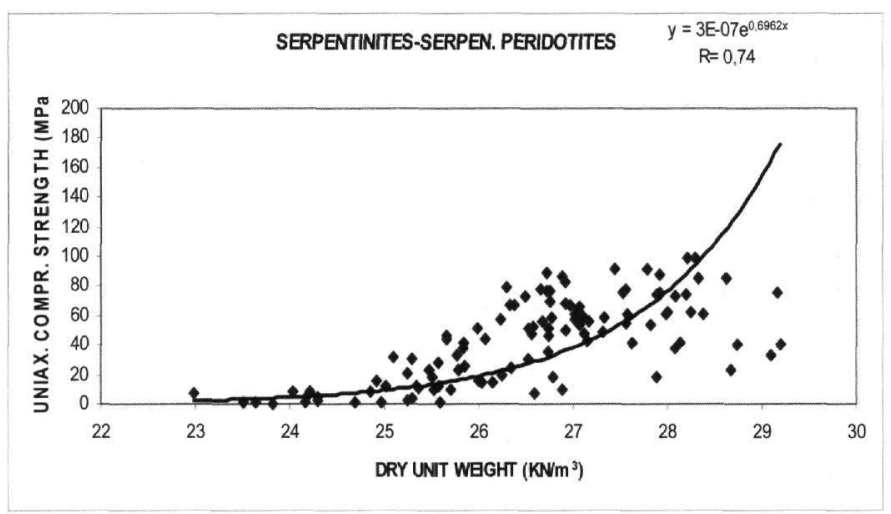

Figure 13 - UCS against Dry unit weight combining Serpentinised Peridotites and Serpentinites

\section{Conclusions}

Due to the petrographic variety, the grade of serpentinisation, preferred orientation of olivine and orthopyroxene, the structural complexity and the internally imprinted tectonic deformation, ultrabasic rocks were divided in three groups (Peridotites, Serpentinised Peridotites and Serpentinites). Each group presents a wide range of geomechanical and physical properties.

This paper demonstrates that for ultrabasic rocks, the relationship between UCS and $\gamma$ gives a good correlation coefficient $(\mathrm{R}=0.66)$ and is defined by the equation $\mathrm{UCS}=0.0063 \mathrm{e}^{0.3117 \gamma}$. For the Peridotites only, the relationship between UCS and $\gamma$ gives a high correlation coefficient $(\mathrm{R}=0.78)$ and is represented by $\mathrm{UCS}=0.2067 \mathrm{e}^{0.1892 \cdot \gamma}$. As far as Serpentinised Peridotites are concerned, the relationship between UCS and $\gamma$ presents a low correlation coefficient $(\mathrm{R}=0.26)$ in contrast to Serpentinites $(R=0.66)$. It was realized that the examination of Serpentinised Peridotites and Serpentinites together provides a good correlation coefficient $(0.74)$ and the new equation is defined by the UCS $=3 \cdot 10^{-7} \mathrm{e}^{0.6962 \cdot \gamma}$. It is obvious that the determination of UCS value with an easy and economical way (estimation of $\gamma$ ) can provide an important help to the geotechnical engineers.

Furthermore, the majority of the ultrabasic samples were fractured in one angle, which mainly varied between $75^{\circ}$ and $90^{\circ}$. The samples broken in two fractures, presented an increase of the percentage of the bins $45^{\circ}-59^{\circ}$ and $60^{\circ}-74^{\circ}$ while the percentage of the bin $75^{\circ}-90^{\circ}$ got decreased. Moreover, the fracture angles of $30^{\circ}-44^{\circ}$ were mainly correlated with low angle thrusts, the bin of $45^{\circ}-59^{\circ}$ corresponds to the thrusts and that of $60^{\circ}-90^{\circ}$ to the faults or collapse effects. 
Finally, there is no apparent relationship between the fracture angle and the depth from which the sample was taken and between the UCS and the fracture angle.

\section{References}

Ferriere, J., 1982. Paleogeographies et Tectoniques Superposees dans les Hellenides Internes au Niveau de l' Othrys et de Pelion (Grece), Univ. des Sciences et Techniques de Lille.

I.S.R.M., 1981. Suggested methods for determining the uniaxial compressive strength and deformability of rock materials, International Society of Rock Mechanics, Commission on standardization of laboratory and field tests, 111-116pp.

Katsikatsos, G., Migiros, G., Triantaphyllis, M., and Mettos, A., 1986. Geological structure of internal Hellenides (E. Thessaly-SW Macedonia, Euboea-Attica-Northern Cyclades islands and Lesvos). I.G.M.E., Geol. and Geoph. Res., Special Issue, 191-212.

Koumantakis, J., 1982. Comportement des peridotites et serpentinites de la Grece en travaux public. Leur propretes physiques et mechaniques, Bul IAEG, 25, 53-60.

Marinos, G., 1974. Geology of Othrys and issues on its ophiolites, Ann. Geol. Des Pays Hell., University of Athens, 118-148.

Marinos, P., Hook, E., and Marinos, V., 2006. Variability of the engineering properties of rock masses quantified by the geological strength index: the case of ophiolites with special emphasis on tunneling, Bull. Eng. Geol. Env. 65, 129-142.

Migiros, G., 1990. The lithostratigraphic-tectonic structure of Othris (Central Greece), Bull. of the Geol. Society of Greece, XXVI, 107-120.

Mountrakis, D., Sapountzis, E., Kilias, A., Eleftheriadis, G., and Christofides, G., 1983. Paleogeographic conditions in the western Pelagonian margin in Greece during the initial rifting of the continental area, Canadian Journal of Ear. Sc., 20, 1673-1681.

Paventi, M., Scoble, M., and Stead, D., 1996. Characteristics of a complex Serpentinised Ultramafic Rock Mass at the Birchtree Mine, Manitoba. In H. Aubertin, Mitri (ed.), North American Rock Mechanics Symposium, Rotterdam, 339-346pp. 